\title{
Spatial and temporal patterns of settlement of the brown macroalgae Turbinaria ornata and Sargassum mangarevense in a coral reef on Tahiti
}

\author{
V. Stiger*, C. E. Payri \\ Laboratoire d'Ecologie Marine, Université Française du Pacifique, BP 6570 Faaa/Aéroport, Tahiti, French Polynesia
}

\begin{abstract}
Turbinaria ornata and Sargassum mangarevense are the most conspicuous macroalgal species that grow on the reefs of Tahiti and other high islands of French Polynesia. This study reports on a quantitative investigation of spatial and seasonal settlement efficiencies and dispersal distances for these 2 species in a coral reef habitat on Tahiti. Settlement patterns of germlings were observed in situ on settlement plates placed around parental thalli during 2 seasons (hot and cold). For both species, the dispersal of germlings was limited to within $90 \mathrm{~cm}$ of the parental thalli, and the greatest number of settled germlings was observed during the cold season. $T$ ornata showed a higher attachment ability and lower dispersal distances than $S$. mangarevense. A model of dispersal is suggested for the 2 species showing a decrease in germling number with distance from parental thalli. Dispersal of germlings appears to be influenced by the dominant current during their release. This short-distance dispersal allows rapid establishment and maintenance of local populations, and is consistent with the explanation of the metapopulation distribution of the 2 species. The 2 species did not release all oogonia present in their reproductive structures. $T$ ornata had a stock of oogonia that varied seasonally (with low amounts during the hot season), whereas there was no seasonal variation in the oogonia stock of $S$. mangarevense. Recently, isolated atolls have been settled by $T$. ornata but not by $S$. mangarevense. It is proposed that the tendency for fertile thalli of $T$. ornata to float over long distances, combined with its oogonia stock and higher settlement efficiencies, could account for its greater capacity to colonize new areas, as compared to $S$. mangarevense.
\end{abstract}

KEY WORDS: Settlement efficiencies - Dispersal distances - Oogonia stock - Spatial and seasonal variations · Turbinaria ornata Sargassum mangarevense · Coral reefs · French Polynesia

\section{INTRODUCTION}

Coral reefs provide a highly specialized habitat in which benthic algae are abundant, and in many places dominant. In French Polynesia, Turbinaria ornata and Sargassum mangarevense, 2 brown macroalgae, have thrived on the reefs of high islands over the past 2 decades (Payri \& Naim 1982, Done et al. 1991). Since 1985, only $T$. ornata has settled in the lagoons of atolls (Montaggioni et al. 1985, Payri \& N'Yeurt 1997), demonstrating that it has the ability to disperse over long distances. Some species appear to have 2 modes of dispersal for habitat colonization (Santelices 1990), i.e.

\footnotetext{
- Present address: Division of Biological Sciences, Graduate School of Science, Hokkaido University, Sapporo 060-0810. Japan.E-mail:vstiger@sci.hokudai.ac.jp
}

short-distance dispersal of germlings released by attached thalli, and long-distance dispersal of germlings released by whole or partial thalli drifting over many kilometers (Morrissey 1985, Van den Hoek 1987, Kilar $\&$ Norris 1988, Norton 1992). The dispersal distance is known to be low for fucalean algae such as species of Sargassum (Fletcher \& Fletcher 1975, Deysher \& Norton 1982, Critchley 1983, De Ruyter van Steveninck \& Breeman 1987, Kendrick \& Walker 1991) and Fucus (Menge et al. 1993).

In the present study, the short-distance dispersal was investigated for Turbinaria ornata and Sargassum mangarevense. These 2 species are able to produce and release sperm and eggs throughout the year with minor spatial and temporal variations (Stiger \& Payri 1999). Hence they are in direct competition for space with other benthic organisms such as corals, which broad- 
cast their gametes or larvae seasonally (Jardin 1994). The colonization of new substrata is the most fundamental process in the life history of attached benthic organisms. Hence a better understanding of colonization will lead to a better understanding of patch size, distribution and invasive tendencies of benthic marine algae.

Previous measurements of dispersal have not considered the fertility of the parent plants and the losses incurred during dispersal, as it is difficult to recognize the source of the germlings. Here we identify the germlings by staining them at their source and we estimate dispersal directly from parent thalli using settlement plates in the field. Spatial and seasonal variations in settlement efficiencies and dispersal distances of germlings were investigated in order to propose a dispersal model for both species. The efficiency of reproduction was estimated by determining: (1) the ratio of germlings produced to germlings released by parent thalli, and (2) the losses during dispersal in relation to the fertility of parent thalli before and after dispersal. A better understanding of the settlement of these 2 algae will lead to possible future management of populations.

\section{MATERIALS AND METHODS}

The study was conducted on the Taapuna barrier reef on the northwest coast of Tahiti, French Polynesia (Fig. 1A). The reef site spreads over $500 \mathrm{~m}$ from the reef margin and consists of a relatively deep area, $2.5 \mathrm{~m}$ average depth, where coral colonies are well developed and scattered amongst coralline sand accumulations, as described previously by Stiger \& Payri (1999).

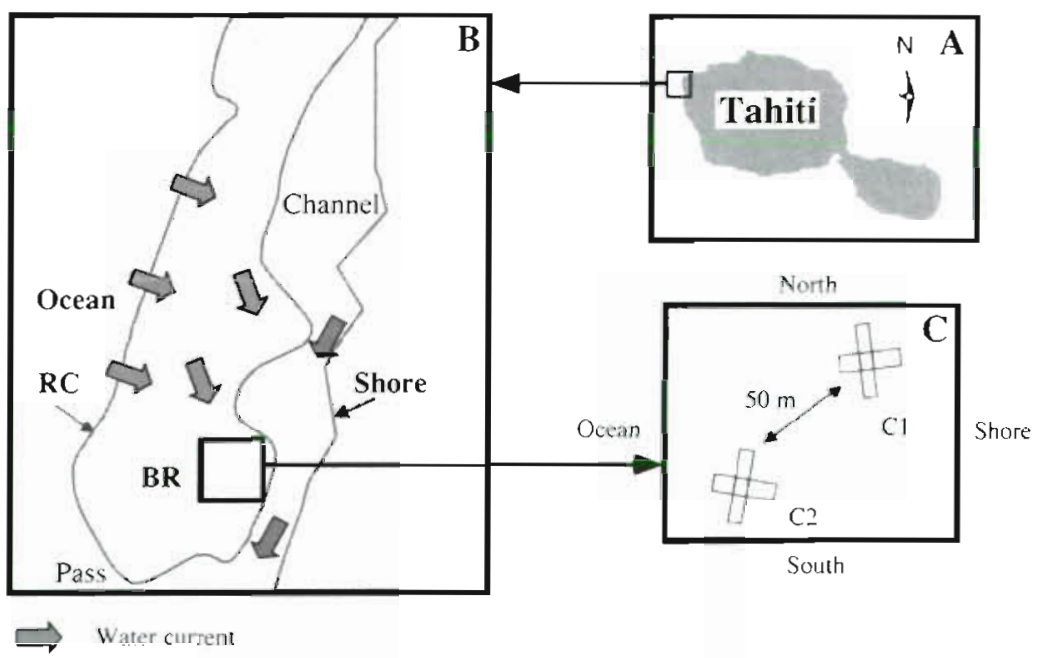

Fig. 1. The study site. (A) Map of Tahiti island. (B) Localization of the study area on the inner barrier reef. (C) Disposition of the 2 setups on the study area RC: reef crest. BR: barrier reef. $\mathrm{C} 1$ and $\mathrm{C} 2$ are the 2 setups
Experimental design. Experiments were carried out between December 1995 and April 1996 (hot season), and in July 1996 (cold season), to test for seasonal variation in dispersal. Two experimental setups were fixed on the flat upper part of 2 dead coral colonies of more than $4 \mathrm{~m}^{2}$, located on the internal reef flat: about $10 \mathrm{~m}$ (C1) and $50 \mathrm{~m}$ (C2) from the margin of a channel (Fig. 1B). The setups consisted of ceramic tiles laid out approximately parallel ( $W$ to $E$ ) and perpendicular $(N$ to $S$ ) to the water current direction. Generally the water circulation at the study site occurs from the ocean towards the shore (Fig. 1B); however, depending on the wind regime this situation can sometimes be reversed (Lenhardt 1991). The 2 experimental setups were approximately $50 \mathrm{~m}$ apart (Fig. 1C) and permanently submerged, even during low tides, and they were carried out at the same times. Each experimental setup had 4 sets of 5 settlement tiles $(0.3 \times 0.3 \mathrm{~m})$ arranged in a cross (Fig. 2A). Each arm of the cross was composed of 3 contiguous tiles located towards the middle of the setup, covering a distance of $0.9 \mathrm{~m}$, and 2 tiles placed $2 \mathrm{~m}$ from the middle of the setup. Each tile was divided into 169 small squares to facilitate the counting of settled germlings (Fig. 2B). The roughness of the ceramic tiles is similar to coral surfaces and provides an inert texture with presumably no negative impact on germling settlement. The ceramic tiles were brushed and cleared of epiphytes before each experiment and fixed with nails on the coral colonies after all the fucalean algae were removed around the setup.

Staining of germlings. Germlings were stained with Toluidine Blue while they were still attached to parent thalli, as described in Kendrick \& Walker (1991). Stiger (1997) has shown that staining has no effect on release and dispersal of germlings. In order to recover enough germlings following staining, approximately 70 to $80 \mathrm{fe}$ male thalli in Turbinaria ornata and 80 to 120 mature laterals in Sargassum mangarevense were stained (Table 1). All thalli were of similar mean size (19 to $20 \mathrm{~cm}$ for the 2 species), and over $50 \%$ of the thalli had visible oogonia attached at the surface of the conceptacles. Staining was done in the field in a large bin of $0.05 \%$ Toluidine Blue in seawater for 1 to $2 \mathrm{~h}$. Stained thalli were then tied to stakes with soft wires and fixed in the center part of each experimental setup. Four to 5 d later, the settlement plates were collected, and stained germlings were counted within each grid of the tile (Fig. 2B) and mapped in a matrix of coordinates in the field. 
Table 1 Number of individuals collected at each sampling date in Turbinaria ornata and Sargassum mangarevense

\begin{tabular}{|lcc|}
\hline Species & $\begin{array}{c}\text { Date of } \\
\text { sampling }\end{array}$ & $\begin{array}{c}\text { Number of } \\
\text { individuals }\end{array}$ \\
\hline Turbinaria ornata & Dec 1995 & 70 \\
& Feb 1996 & 80 \\
& Jul 1996 & 80 \\
Sargassum mangarevense & Mar 1996 & 80 \\
& Apr 1996 & 100 \\
& Jul 1996 & 120 \\
\hline
\end{tabular}

Settlement and dispersal patterns. Settlement efficiency and dispersal distances were investigated in Turbinaria ornata and Sargassum mangarevense in separate experiments. Settlement efficiency was measured as the number of stained germlings attached to the ceramic tiles per unit area $\left(\mathrm{m}^{2}\right)$ and divided by the number of receptacles estimated in the bundle of stained thalli used in the setup. Settlement efficiencies were determined for each direction in each setup. Dispersal distance was measured as distance traveled by germlings from the parent thalli.

For a given direction, the 3 contiguous tiles were stratified, with the number of attached germlings as a stratifying variable, considering preliminary results on distance variation in germlings density after dispersal.
Table 2. Distances and sampling areas used for the measurement of dispersal distance in Turbinaria ornata and Sargassum mangarevense

\begin{tabular}{|cccc|}
\hline $\begin{array}{c}\text { Distance } \\
(\mathrm{m})\end{array}$ & $\begin{array}{c}\text { Sampling area } \\
\left(\mathrm{m}^{2}\right)\end{array}$ & $\begin{array}{c}\text { Sargassum mangarevense } \\
\text { Distance } \\
(\mathrm{m})\end{array}$ & $\begin{array}{c}\text { Sampling area } \\
\left(\mathrm{m}^{2}\right)\end{array}$ \\
\hline 0.092 & 0.0275 & 0.046 & 0.0139 \\
0.184 & 0.0275 & 0.092 & 0.0139 \\
0.322 & 0.0413 & 0.162 & 0.0208 \\
0.483 & 0.0481 & 0.254 & 0.0277 \\
0.667 & 0.0550 & 0.485 & 0.0692 \\
0.900 & 0.0688 & 0.900 & 0.1246 \\
2.000 & 0.1800 & 2.000 & 0.1800 \\
\hline
\end{tabular}

Within each stratum, the mean number of germlings was determined, and for the 4 directions the same strata were considered throughout the study for a given species to carry out all statistical comparisons. Stratification limits were determined for each species and the dispersal distance corresponded to the upper limit of each stratum (Table 2). Stained germlings were hence counted on each tile over an increasing area in relation to the distance from the parent thalli, taking into account the phenomenon of dilution.

Spatial and seasonal variations in settlement and dispersal were determined from the data provided respectively with the 2 setups ( $\mathrm{C} 1$ and $\mathrm{C} 2$ ) and the 2 seasons.

The experiment was run 2 times during the hot season and only 1 time during the cold season. Indeed, algae did not liberate their gametes after July 1996 because of the absence of low tides, due to a lowpressure weather system on Tahiti.

Using the software 'Super Anova for Macintosh', 3-way ANOVA tests were performed on the number of germlings attached $\mathrm{m}^{-2}$ receptacle ${ }^{-1}$ (dependent variable) with: (1) factor 'setup' to show spatial patterns, (2) factor 'season' to show temporal patterns, and (3) 'dispersal distance' to show exactly how far germlings settled from parent thalli. No germling was found attached to the tiles placed $2 \mathrm{~m}$ from the parent thalli. This stratum was thus not included in comparisons applying ANOVA (homogeneity of variances). Tukey's pairwise comparisons were carried out in order to compare dispersal distances and to constitute homogeneous groups.

Dispersal model. Spatial and temporal variability of settlement efficiencies of germlings were integrated in a general model describing the dispersal pat-
Fig. 2. Experimental design of the dispersal distances of Turbinaria ornata and Sargassum mangarevense. (A) Schematic design of 1 setup with cardinal directions (W, N, E and S). (B) Detail of 1 ceramic tile. (C) Sampling design; A: real area colonized by germlings, As: real area sampled 
terns of the 2 species. The sampling scale is the square size unit within the settlement tiles. For the $n_{i}$ squares, the attached germlings were counted and the number of germlings per line was used to construct an $x$ - $y$ matrix, as proposed by He et al. (1996), where $X$ and $Y$ represent the centered geographical coordinates of each line in the measurement setup. Equating of each relationship was carried out using a multiple regression model, where the dependent variable was the number of settled germlings $\mathrm{m}^{-2}$ receptacle ${ }^{-1}$. A multiple correlation coefficient, $R^{2}$, was calculated to indicate the proportion of the variation in the number of germlings explained by the model. The dispersal of germlings was not homogeneous around parent thalli, and a multiple regression model was proposed for each direction; the number of attached germlings was a function of the distance from parent thalli ( $X$ or $Y$ according to the direction being looked at). The number of attached germlings was included into a polynomial equation according to the direction being considered:

$$
\text { or } \begin{aligned}
\text { Density } & =a X+b X^{2}+c X^{3}+\ldots+K \\
\text { Density } & =a Y+b Y^{2}+c Y^{3}+\ldots+K
\end{aligned}
$$

with $\mathrm{K}$, the constant.

Beforehand, equation coefficients for which contribution was insignificant ( $p>0.05$ ) were eliminated. We used data from tiles located $2 \mathrm{~m}$ from the parent thalli, even though no germlings were ever found attached to settlement plates at that distance. Variation in the number of attached germlings with respect to distance from the parent thalli was represented as a 3-dimensional graph symbolizing the experimental setup.

Fertility before and after dispersal. We attempted to quantify parameters of the equation:

$$
F b d=N t+F a d+L
$$

where Fbdis the fertility before dispersal, $N t$ is the total number of attached germlings, Fad is the fertility after dispersal, and $L$ is the loss of germlings during dispersal.

Fertility before and after dispersal (Fbd and Fad): Before and after each experiment, batches of female individuals (Turbinaria ornata) or mature laterals (Sargassum mangarevense) were collected and examined to obtain the mean number of oogonia per individual, using the method described by Stiger \& Payri (1999). The oogonia in 5 non-stained thalli collected near the experimental setups were counted to assess Fbd. The oogonia in 5 stained thalli taken from the parental thalli in the setup were counted to assess Fad. This allowed an assessment of any variations linked to transplantation and staining.

Total number of attached germlings ( $N t)$ : In our experiments, germlings were released in all directions and settled within a radius of $0.9 \mathrm{~m}$ (Fig. 2C). The num- ber of attached germlings $(N f)$ for a given direction was estimated using the formula:

$$
N f=\frac{X \cdot A}{A s}
$$

where $A$ is the total area colonized by the germlings, $x$ is the number of germlings counted per direction and As is the area sampled in our study (Fig. 2C). The total number of attached germlings around the parent thalli $(N t)$ was obtained by adding the $N f$ values for each of the 4 directions.

Loss of germlings during dispersal (L): The number of germlings lost during dispersal was calculated as: $L=F b d-F a d-N t$ (from Eq. 3 above).

\section{RESULTS}

\section{Settlement efficiencies and dispersal distances}

\section{Spatial variations}

The germlings of the 2 species settled within $0.9 \mathrm{~m}$ of parent plants in the 2 setups (Fig. 3). For Turbinaria ornata, the greater number of germlings dispersed over a distance of $0.18 \mathrm{~m}$ from parent thalli, then settlement density declined gradually with distance (Fig. 3A). Dispersal distances had a significant effect ( $p=0.0001$; Tukey's pairwise comparisons) on the variability of the number of germlings $\mathrm{m}^{-2}$ receptacle ${ }^{-1}( \pm \mathrm{SE})$, while the location of the setup did not affect the density of the germlings ( $p=0.0395$ ). The mean settlement efficiency was $2.717( \pm 0.251)$ for setup C1 and $2.709( \pm 0.182)$ for setup $C 2$. Even though differences in dispersal distance were recorded between the 2 setups, they were not caused by the setup itself $(p=0.1320)$.

The pattern of dispersal for Sargassum mangarevense was significantly affected by the setup and the dispersal distance $(p=0.0001)$. Moreover, there was a significant interaction between these 2 factors $(p=0.0032)$. At the $5 \%$ significance level (Tukey's pairwise comparisons), the mean settlement efficiency was significantly higher in C1 $(0.308 \pm 0.025$ germlings $\mathrm{m}^{-2}$ receptacle $\left.{ }^{-1}\right)$ than in $\mathrm{C} 2(0.190 \pm 0.013)$. On C1, the greatest density of germings occurred between 0.09 and $0.25 \mathrm{~m}$ from their source (Fig. 3B); beyond $0.25 \mathrm{~m}$ the settlement declined with distance (Fig. 3B). On C2, the highest number of germlings was observed at a distance of $0.09 \mathrm{~m}$ from the parent thalli. Thereafter, the number of attached germlings decreased. Thus, the 2 species were significantly different in their dispersal patterns. Turbinaria ornata had shorter dispersal distances which did not vary with environmental conditions, and $S$. mangarevense had variable dispersal distances which varied over time. The differences 

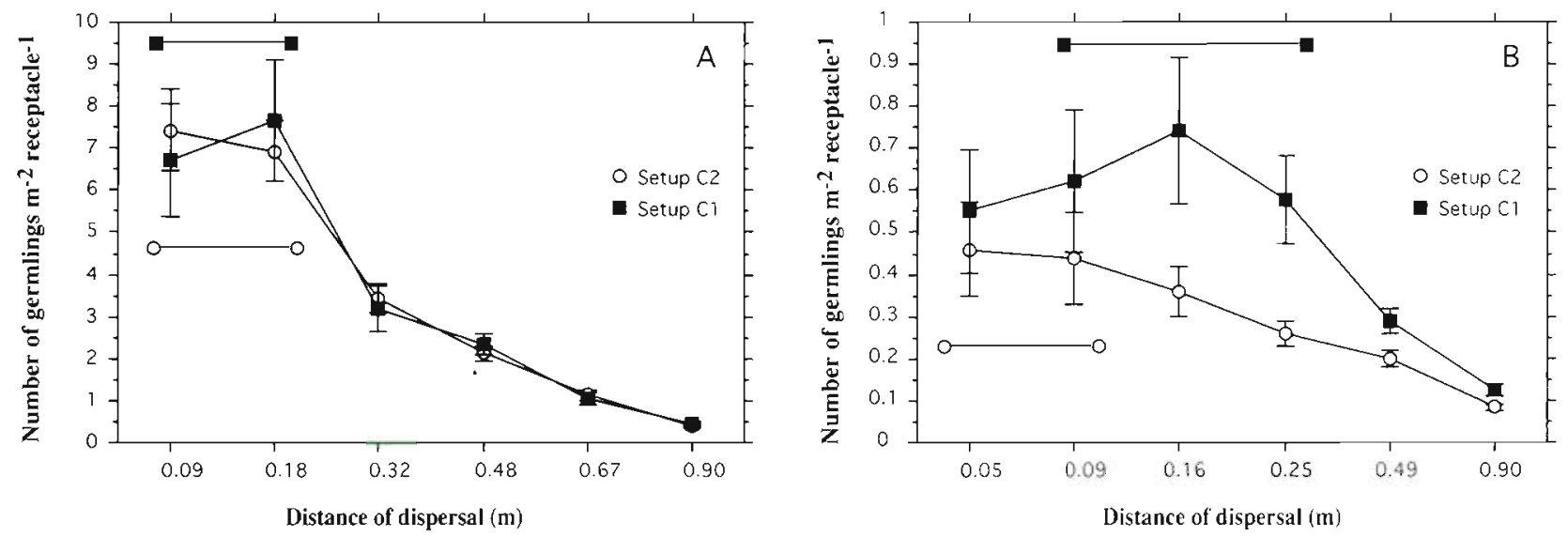

Fig. 3. Effect of setup on variations of the number of germlings $\mathrm{m}^{-2}$ receptacle ${ }^{-1}$ with distance ( $\mathrm{m}$ ) from the parent thalli of (A) Turbinaria ornata and (B) Sargassum mangarevense. C1 and C2 represent the 2 different setups

in the dispersal distances in $\mathrm{C} 1$ and $\mathrm{C} 2$ may be related to the stronger water currents in $\mathrm{C} 1$.

\section{Seasonal variations}

The settlement efficiency and dispersal pattern of Turbinaria ornata germlings showed significant seasonal variation ( $p=0.0001$, Fig. $4 A$ ). Settlement efficiency was higher during the cold season; significantly more germlings settled during the cold season $\left(5.268 \pm 0.404\right.$ germlings $\mathrm{m}^{-2}$ receptacle $\left.{ }^{-1}\right)$ than during the hot season $(1.436 \pm 0.074)$. The hot season study showed the highest germling settlement at a distance of $0.18 \mathrm{~m}$ from the parent thalli, whereas germling dispersal was limited to within $0.18 \mathrm{~m}$ during the cold season. In both seasons, germling density declined with distance beyond $0.18 \mathrm{~m}$.

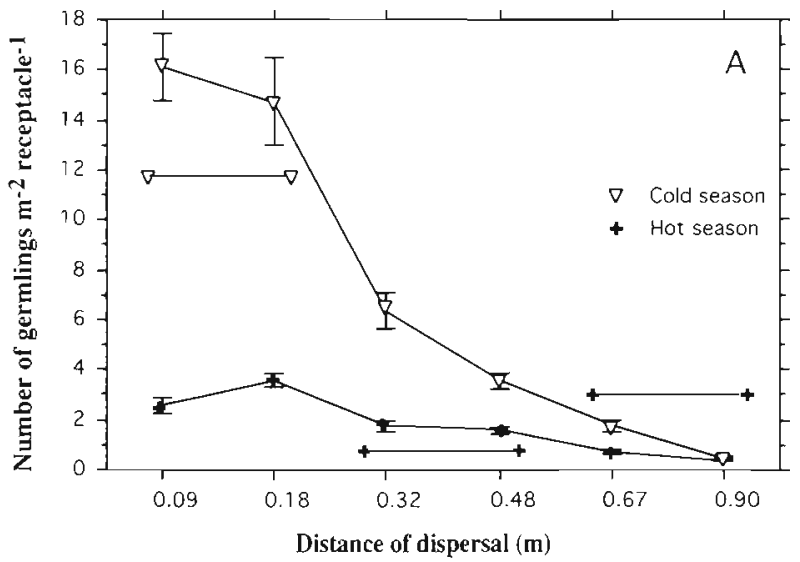

The settlement efficiency and dispersal pattern of Sargassum mangarevense germlings also differed significantly with season ( $p=0.0001$, Fig. 4B). Settlement efficiency was slightly higher during the cold season than during the hot season $(0.297 \pm 0.025$ and 0.225 \pm 0.017 germlings $\mathrm{m}^{-1}$ receptacle ${ }^{-1}$, respectively). Dispersal distance was greater during the hot season, when germlings settled between 0.09 and $0.49 \mathrm{~m}$ from parent thalli. During the cold season, germling settlement occurred mainly within $0.16 \mathrm{~m}$ from the parent (Fig. 4B)

Hence, for both species, more germlings settled during the cold season and dispersal distances were greater during the hot season. Using the ratio between the number of attached germlings and the number of thalli as a measure of reproductive efficiency, Turbinaria ornata appears to have a higher attaching ability than Sargassum mangarevense.

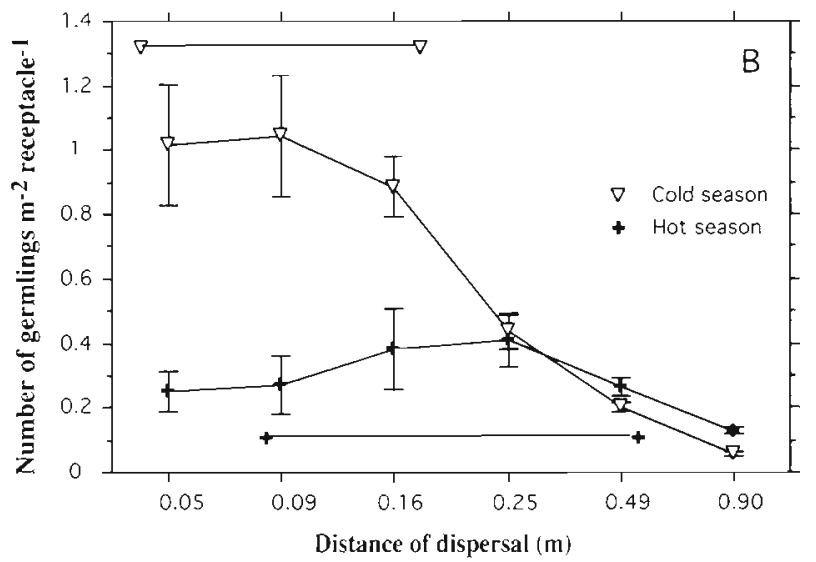

Fig. 4. Effect of season on the variations of the number of germlings $\mathrm{m}^{-2}$ receptacle ${ }^{-1}$ with distance ( $\mathrm{m}$ ) from the parent thalli of (A) Turbinaria ornata and (B) Sargassum mangarevense 


\section{Dispersal model}

Variation in the number of settled germlings as a function of distance was modeled for the 2 species using polynomial equations (Table 3). The number of germlings $\mathrm{m}^{-2}$ receptacle ${ }^{-1}$ was different according to the direction of the setup and to the distance from the parent thalli (symbolized by the middle of Fig. 5).

From predicted values, $54.6 \%$ of Turbinaria ornata germlings dispersed mainly in a southerly direction (Fig. 5A). Directions west (i.e. towards the ocean) and east (i.e. shoreward) added up to a lower total number of settled germlings than south ( 14.7 and $22 \%$, respectively). Finally, few germlings attached in the north direction $(8.7 \%) . T$. ornata germlings generally attached near the base of the parent thalli and their number decreased with distance, but differently according to direction. For the direction west, the decrease took place rapidly: no germling was found at a distance of $0.50 \mathrm{~m}$ from the parent thalli. For the 3 other directions, germlings dispersed to a distance of $0.90 \mathrm{~m}$. For the direction east, values did not fit correctly to the proposed model $\left(R^{2}=0.587\right.$, Table $\left.3 A\right)$. For the direction south, a rise was noted in germling settlement at a distance of $0.90 \mathrm{~m}$ from the parent thalli, showing that the model did not properly fit the data collected.

Sargassum mangarevense germlings attached mainly in direction west, totaling $31.1 \%$ of all germlings attached in the setup (Fig. 5B). For the 3 other directions, germings attached themselves more homogeneously; $21.1 \%$ in north, $23.8 \%$ east, and $24 \%$ south direction. The highest settlement efficiency was observed at the base of the parent thalli, i.e. at a distance of $0.02 \mathrm{~m}$. The number of attached germlings decreased differently according to the direction being considered. For north direction, germlings had a higher dispersal distance compared to the other 3 directions. Some germlings were found attached at a distance of $0.90 \mathrm{~m}$ in all directions, but only very few. The direction south showed a new rise in the number of germlings, as seen in $T$ ornata for the same direction. Here again, the model did not seem to fit perfectly with the data obtained, since no germlings were found on tiles placed $2 \mathrm{~m}$ from the parent thalli $\left(\mathrm{R}^{2}=0.759\right.$, Table $\left.3 \mathrm{~B}\right)$.

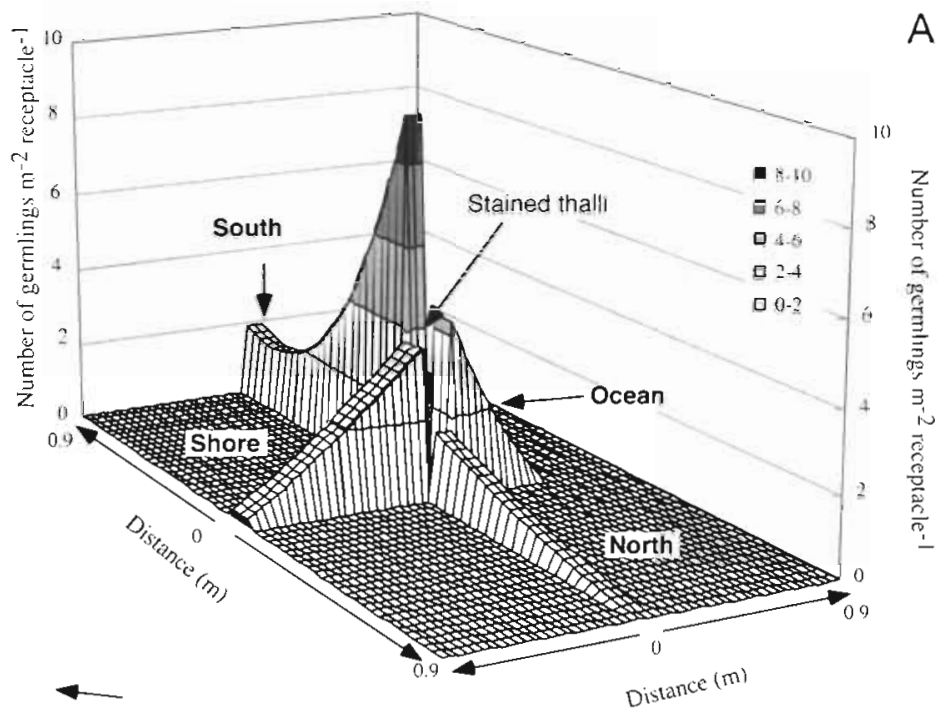

Direction of the main current

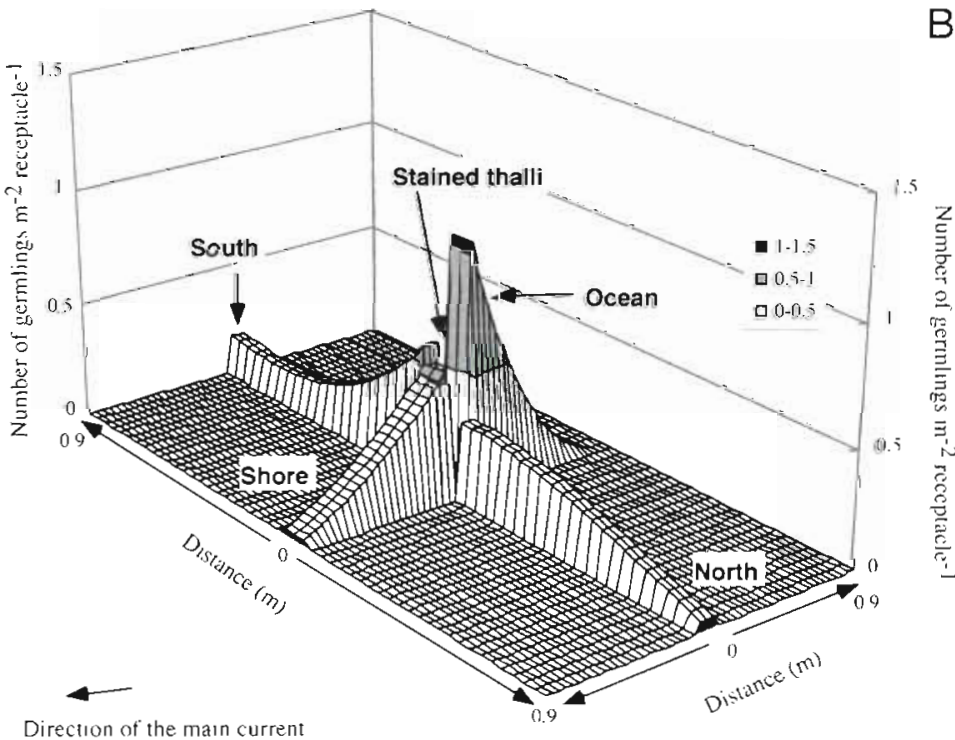

Fig. 5. Variations of the number of germlings $\mathrm{m}^{-2}$ receptacle ${ }^{-1}$ with distance and direction from the parent thalli in (A) Turbinaria ornata and (B) Sargassum mangarevense

\section{Efficiency of germling establishment}

Germlings found on the settlement plates represent a small proportion of the total number released by parent thalli in the experiments. It is estimated that only 0.004 and $0.003 \%$ of Turbinaria ornata germlings were recovered in December 1995 and February 1996, respectively (Table 4A). Indeed, in December 1995, losses were similar between stained and unstained thalli (72.9 and $64.3 \%$ ) which indicates similar environmental conditions for the 2 kinds of thalli. Thalli did not release all 
Table 3. Model of polynomial regression between the number of attached germlings and the distance from the parent thalli, in the system of coordinates $X$ and $Y$, for each sampled direction. (A) Turbinaria ornata, (B) Sargassum mangarevense. $\mathrm{N}=$ north, $\mathrm{S}=$ south

\begin{tabular}{|c|c|c|c|c|c|c|}
\hline \multirow{2}{*}{ Direction } & \multirow{2}{*}{ Variable } & \multicolumn{3}{|c|}{$\longrightarrow t$-test } & \multicolumn{2}{|c|}{ Multiple regression } \\
\hline & & Coefficient & t-value & $\mathrm{p}$ & $\mathrm{R}^{\frac{1}{2}}$ & $\mathrm{p}$ \\
\hline \multicolumn{7}{|c|}{ (A) Turbinaria ornata } \\
\hline $\mathrm{N}$ & $\begin{array}{c}Y \\
Y^{2} \\
\text { Constant }\end{array}$ & $\begin{array}{l}-0.028 \\
0.0001 \\
1.697\end{array}$ & $\begin{array}{l}8.357 \\
5.346\end{array}$ & $\begin{array}{l}0.0001 \\
0.0001\end{array}$ & 0.723 & 0.0001 \\
\hline$O(=$ Ocean $)$ & $\begin{array}{c}X \\
X^{2} \\
X^{3} \\
\text { Constant }\end{array}$ & $\begin{array}{l}-0.127 \\
0.001 \\
-0.000003 \\
4.33\end{array}$ & $\begin{array}{l}6.276 \\
3.915 \\
3.096\end{array}$ & $\begin{array}{l}0.0001 \\
0.0004 \\
0.0038\end{array}$ & 0.811 & 0.0001 \\
\hline $\mathrm{s}$ & $\begin{array}{c}Y \\
Y^{2} \\
Y^{3} \\
\text { Constant }\end{array}$ & $\begin{array}{l}-0.225 \\
0.002 \\
-0.0000045 \\
9.141\end{array}$ & $\begin{array}{l}6.388 \\
3.403 \\
2.427\end{array}$ & $\begin{array}{l}0.0001 \\
0.0016 \\
0.0204\end{array}$ & 0.866 & 0.0001 \\
\hline E (= Shore) & $\begin{array}{c}X \\
X^{3} \\
\text { Constant }\end{array}$ & $\begin{array}{l}-0.044 \\
0.00000065 \\
3.739\end{array}$ & $\begin{array}{l}6.609 \\
3.381\end{array}$ & $\begin{array}{l}0.0001 \\
0.0017\end{array}$ & 0.587 & 0.0001 \\
\hline \multicolumn{7}{|c|}{ (B) Sargassum mangarevense } \\
\hline $\mathrm{N}$ & $\begin{array}{c}Y^{2} \\
Y^{3} \\
\text { Constant }\end{array}$ & $\begin{array}{l}-0.000056 \\
0.00000024 \\
0.326\end{array}$ & $\begin{array}{l}7.32 \\
8.717\end{array}$ & $\begin{array}{l}0.0001 \\
0.0001\end{array}$ & 0.734 & 0.0001 \\
\hline$O(=$ Ocean $)$ & $\begin{array}{c}X \\
X^{2} \\
X^{3} \\
\text { Constant }\end{array}$ & $\begin{array}{l}-0.027 \\
0.00022 \\
-0.00000057 \\
1.047\end{array}$ & $\begin{array}{l}5.789 \\
3.161 \\
2.279\end{array}$ & $\begin{array}{l}0.0001 \\
0.0032 \\
0.0287\end{array}$ & 0.834 & 0.0001 \\
\hline $\mathrm{S}$ & $\begin{array}{c}Y \\
Y^{2} \\
Y^{3} \\
\text { Constant }\end{array}$ & $\begin{array}{l}-0.015 \\
0.00016 \\
-0.00000049 \\
0.58\end{array}$ & $\begin{array}{l}7.247 \\
4.985 \\
4.298\end{array}$ & $\begin{array}{l}0.0001 \\
0.0001 \\
0.0001\end{array}$ & 0.824 & 0.0001 \\
\hline$E(=$ Shore $)$ & $\begin{array}{c}X \\
X^{2} \\
\text { Constant }\end{array}$ & $\begin{array}{l}-0.008 \\
0.000026 \\
0.537\end{array}$ & $\begin{array}{l}8.733 \\
5.19\end{array}$ & $\begin{array}{l}0.0001 \\
0.0001\end{array}$ & 0.759 & 0.0001 \\
\hline
\end{tabular}

For Sargassum mangarevense, the percentage of settled germlings was low $(0.003 \%)$ and did not vary throughout the study period (Table 4B). Even though the comparison between the stained lateral and reference batches was difficult, a weak release and loss of oogonia (around 0.9\%) was noticed in April 1996. In March and July 1996 , both stained laterals and reference laterals released, and kept in store, similar amounts of oogonia. We conclude that there is no seasonal variation in oogonia production, germling settlement and oogonia stock in S. mangarevense.

\section{DISCUSSION}

Our results show that germlings released by Turbinaria ornata and Sargassum mangarevense disperse passively and settle close to the parent thalli. These results are consistent with those of prior studies, which suggest that for numerous perennial brown algae, dispersal is limited to a few meters from the parent thalli (Anderson \& North 1966, Dayton 1973, Deysher \& Norton 1982, De Ruyter van Steveninck \& Breeman 1987, Reed et al. 1988, Kendrick \& Walker 1991, Norton 1992). This has also been found for some red algae (Destombe et al. 1992, Menge et al. 1993) and seagrasses (Orth et al. 1994). In these stu-

their oogonia; after dispersal 27.1 and $35.7 \%$ of oogonia were still present in receptacles on stained and unstained thalli, respectively. In February 1996, the percentage of settled germlings $(0.003 \%)$ was comparable to that obtained the previous month $(0.004 \%)$. Losses were nevertheless more important: $88.9 \%$ for stained and reference thalli. The fertility after dispersal was lower than the previous month in both batches (11.1\%). During the cold season, germling settlement was 10 times greater $(0.034 \%)$ than during the hot season $(0.003$ and $0.004 \%)$. Losses were lower: i.e. $15.6 \%$ for reference thalli and $43.4 \%$ for stained thalli. Following dispersal, thalli showed a more important fertility than during the hot season. Indeed, $56.6 \%$ of oogonia in stained thalli and $84.4 \%$ in reference thalli were not released. T. ornata had the largest stock of oogonia during the cold season. We conclude that seasonal variation exists in $T$ ornata oogonia stock. dies, the dispersal distances of germlings were dependent on 3 main factors: (1) the mass of the germling, (2) the current velocity, and (3) the size of the parent thalli.

Germling mass. The short dispersal distance observed in both species was mainly linked to the falling velocity (sedimentation velocity) of the germling, which is a factor of its size at the time of its release into the environment (Norton \& Fetter 1981). In our study, germlings were released at an advanced multicellular stage and had several rhizoidal buds, which leads to a more rapid sedimentation (Deysher \& Norton 1982, Reed et al. 1988). We also noted that germlings of Sargassum mangarevense showed higher dispersal distances than those of Turbinaria ornata. This may be due to the smaller size of the germlings of $S$. mangarevense $(305 \mu \mathrm{m})$ in comparison with germlings of $T$. ornata (513 $\mu \mathrm{m})$ (Stiger 1997). 
Table 4. Comparison of fertility and losses between stained and control (not stained) (A) individuals of Turbinaria ornata and (B) laterals of Sargassum mangarevense. Nt: total number of attached germlings (in \%). L: loss during dispersal (in \%). Fad: fertility after the dispersion of germlings. The fertility before dispersion (Fbd) was $100 \%$

\begin{tabular}{|c|c|c|c|}
\hline Month & Parameter & $\begin{array}{l}\% \text { of stained } \\
\text { individuals }\end{array}$ & $\begin{array}{l}\% \text { of control } \\
\text { individuals }\end{array}$ \\
\hline \multicolumn{4}{|c|}{ (A) Turbinaria ornata } \\
\hline \multirow[t]{2}{*}{ Dec 1995} & $\begin{array}{c}N t \\
L\end{array}$ & $\begin{array}{c}0.004 \\
72.9\end{array}$ & 64.3 \\
\hline & Fad & 27.1 & 35.7 \\
\hline \multirow[t]{2}{*}{ Feb 1996} & $\begin{array}{c}N t \\
L\end{array}$ & $\begin{array}{c}0.003 \\
88.9\end{array}$ & 88.9 \\
\hline & Fad & 11.1 & 11.1 \\
\hline \multirow[t]{2}{*}{ Jul 1996} & $\begin{array}{c}N t \\
L\end{array}$ & $\begin{array}{c}0.034 \\
43.4\end{array}$ & 15.6 \\
\hline & Fad & 56.6 & 84.4 \\
\hline \multicolumn{4}{|c|}{ (B) Sargassum mangarevense } \\
\hline \multirow[t]{2}{*}{ Mar 1996} & $\begin{array}{c}N t \\
L\end{array}$ & $\begin{array}{c}0.003 \\
39.1\end{array}$ & 61.4 \\
\hline & Fad & 60.9 & 38.6 \\
\hline \multirow[t]{2}{*}{ Apr 1996} & $\begin{array}{c}N t \\
L\end{array}$ & $\begin{array}{c}0.003 \\
0.9\end{array}$ & 43.7 \\
\hline & Fad & 99.1 & 56.3 \\
\hline \multirow[t]{2}{*}{ Jul 1996} & $\begin{array}{c}N t \\
L\end{array}$ & $\begin{array}{c}0.003 \\
43.4\end{array}$ & 73.3 \\
\hline & Fad & 56.6 & 26.7 \\
\hline
\end{tabular}

Velocity. We have shown spatial and temporal variations in dispersal distances and directions. Indeed, germling dispersal was passive and relative to the force and the direction of ocean currents at the moment of their release, as shown by Norton \& Fetter (1981), Deysher \& Norton (1982), Reed et al. (1988) and Richards et al. (1995). Our study did not include data on current velocity, but we can assume that the current changed in speed and direction between the several periods of germling release. Without current, germlings fall directly below receptacles of the parent thalli, as shown by experiments in culture of receptacles (Stiger 1997). In the natural environment, dispersal distances vary according to local current but remain within a meter of the parent thalli. Dispersal can also be made easier during storms, since horizontal transport also depend on resuspension, current speed and sedimentation efficiency (Reed et al. 1988). Our results show that the distribution in Turbinaria ornata and Sargassum mangarevense germlings was not homogeneous around parent thalli; settlement efficiency was higher in the direction of the dominant current. The 2 measurement setups were placed in an area subjected to the action of currents from the reef crest (ocean) and drainage channel. The variations recorded in our study testified to water mass circulation. Moreover, the spatial variations in settlement efficiency of germlings may have resulted from the difference in environmental (hydrological) conditions between the 2 experimental setups. Indeed, the 2 coral colonies were subject to the combined action of waters from the reef crest (ocean) and channel to different extents. The strength. of water movement could lead to a wide dispersal of germlings via horizontal motion through the water column. In this respect, our data differed from that obtained in $S$. spinuligerum by Kendrick \& Walker (1991), who showed an even distribution of germlings around their source. In that latter study, the authors worked on subtidal populations (6 $\mathrm{m}$ depth) where hydrodynamic conditions were more stable than those at our shallow subtidal study sites. The observed seasonal differences and observed differences between species could simply represent differences in current strengths at the time the experiments were conducted.

Parent thalli size. Norton (1992) has shown that the size of individuals releasing germlings, and in particular the location of the receptacles in relation to the base of the thallus, plays a role in the dispersal distance of germlings. However, in our study all the parental thalli were approximatively the same size. Consequently, we can assume that dispersal distance could increase with individuals of a larger size. Similarly, the height difference between the parent thalli and the surface where germlings attach themselves could be a factor influencing settlement efficiency and dispersal distance.

The modeling of dispersal has enabled us to demonstrate a polynomial relationship between the number of attached germlings and dispersal distance. Indeed the settlement efficiency was greatest close to the parent thalli, and progressively decreased with distance. The pattern of dispersal for the fucalean algae Turbinaria ornata and Sargassum mangarevense is comparable to other dispersal models of algal diaspores (Hoffmann 1987, Reed et al. 1988, 1992). These models can be compared to those of terrestrial plant spore or pollen release (Okubo \& Levin 1989, Ribbens et al. 1994), except that the distances vary from meters in algae to kilometers in terrestrial plants.

Differences were noted between the 2 species: the settlement efficiency was higher for germlings of Turbinaria ornata. Afterwards, the dispersal distances were higher for the germlings of Sargassum mangarevense.

From an ecological perspective, this localized dispersal mode can explain the gregarious recruitment which gives rise to populations with contagious distributions. This short-distance dispersal suggests that the population dynamics of Turbinana ornata and Sargassum mangarevense followed a metapopulation model (Destombe et al. 1992, Orth et al. 1994), i.e. 'a population 
structured in distinct units separated by geographical barriers and that breed and evolve sufficiently independent of each other and where migration rates are not very high' (Destombe et al. 1992). Localized dispersal guarantees the settlement of large numbers of germlings in an environment without variations with respect to the parent thalli, where mortality is reduced, and which represents the ideal conditions to ensure their growth. Nevertheless, the major drawbacks in the dispersal model close to the parent thalli can be explained by the mechanical action of the parent thalli moved by the current, the reduction in light intensity and the competition for space among germlings (Kirkman 1981, Deysher \& Norton 1982, Reed \& Foster 1984, Vadas et al. 1992). These negative factors are offset by high germling production, the oogonia stock and the high settlement efficiency of germlings, which could explain the invasion of an area by these 2 species. As soon as a thallus matures it quickly produces around it a population which in turn can spread if substratum is available.

Efficient colonization by benthic algae represents a major risk for other benthic organisms such as corals. The exclusion of the latter by competition for space between algal germlings and coral larvae is a likely hypothesis, considering that the production of coral gametes is usually reduced to a single season (Simpson 1985, Stoddart \& Black 1985, Wallace 1985, Kojis 1986) and in particular for those of French Polynesia (Jardin 1994). Gleason (1996) has shown that a dense cover of algae, particularly Turbinaria ornata, reduces coral recruitment.

The relatively short dispersal of germlings (marginal spread, Farnham 1980) might lead to reproductive isolation of populations. However, dislodgement of entire plants or breakage of portions is common, and these thalli have been observed drifting for long distances. This long-distance transport (remote dispersal) of fertile thalli may account for the arrival of germlings at new, more distant sites. The remote dispersal hypothesis is suggested to explain the settlement of Turbinaria ornata in different atolls of the Tuamotu archipelago. The dispersal of $T$. ornata, therefore, involves both the short-distance dispersal of spores and the long-distance dispersal of fertile thalli. In contrast, Sargassum mangarevense has not settled in the atolls of the Tuamotu. Its absence could be due to the fact that its thalli degrade faster than those of $T$. ornata (V. Stiger pers obs.), probably because they are softer and undergo faster bacterial destruction (E. Deslandes pers. comm.), and hence do not float in the water column long enough to carry their stock of germlings to distant sites. These factors, along with the low settlement efficiencies recorded in the present study, might explain the absence of $S$. mangarevense from these atolls to date.
Long distance dispersal has been shown to be important in the geographical extension of marine algae (Farnham 1980) and will be investigated in further studies on fucales populations in French Polynesia.

Acknowledgements. This research was part of work towards a PhD thesis conducted by V.S. at the Laboratory of Marine Ecology, French University of the Pacific in Tahiti. We acknowledge financial support by the French Ministry of Environment (Office of Research and International Foreign Affairs). Thanks are due to Dr F. Bourdelin for assistance in the field and to Dr A. D. R. N'Yeurt and Dr D. Woodward for revising the English. This manuscript benefited greatly from helpful discussion with $P$. Legendre and the comments of anonymous reviewers for constructive comments on the manuscript.

\section{LITERATURE CITED}

Anderson EK, North WJ (1966) In situ studies of spore production and dispersal in the giant kelp. Macrocystis. Proc 5th Int Seaweed Symp 5:73-86

Critchley AT (1983) The establishment and increase of Sargassum muticum (Yendo) Fensholt populations within the Solent area of southern Britain. I. An investigation of the increase in number of population individuals. Bot Mar 26 $539-545$

Dayton PK (1973) Dispersion, dispersal and persistence of the annual intertidal alga, Postelsia palmaeformis Ruprecht. Ecology 54:433-438

De Ruyter van Steveninck ED, Breeman AM (1987) Population dynamics of a tropical intertidal and deep-water population of Sargassum polyceratium (Phaeophyceae). Aquat Bot 29:139-156

Destombe C, Godin J, Lefevre C, Dehorter O, Vernet P (1992) Differences in dispersal abilities of haploid and diploid spores of Gracilaria verrucosa (Gracilariales, Rhodophyta). Bot Mar 35:93-98

Deysher LE, Norton TA (1982) Dispersal and colonization in Sargassum muticum (Yendo) Fensholt. J Exp Mar Biol Ecol 56:179-195

Done TJ, Dayton PK, Dayton AE, Steger R (1991) Regional and local variability in recovery of shallow coral communities: Moorea, French Polynesia and Central Great Barrier Reef. Coral Reefs 9:183-192

Farnham WF (1980) Studies on alien in the marine flora of southern England. In: Price JH, Irvine DEG, Farnham WF (eds) The shore environment, Vol 2: Ecosystems. Systematics Association Special Volume No. 17(b). Academic Press, London, p 875-914

Fletcher RL, Fletcher SM (1975) Studies on the recently introduced brown alga Sargassum muticum (Yendo) Fensholt. I. Ecology and reproduction. Bot Mar 18:149-156

Gleason M (1996) Coral recruitment in Moorea, French Polynesia: the importance of patch size and temporal variation. J Exp Mar Biol Ecol 207:79-101

He F, Legendre P, LaFrankie JV (1996) Spatial patterns of diversity in a tropical rain forest in vilaysla. J Biogeogr 23:57-74

Hoffmann AJ (1987) The arrival of seaweed propagules at the shore: a review. Bot Mar 30:151-165

Jardin C (1994) Biologie de la reproduction de quelques coraux scléractiniaires en Polynésie française: application 
à la restauration d'un site lagonaire dégradé. Thèse d'Etat, Université Française du Pacifique, Tahiti

Kendrick GA, Walker DI (1991) Dispersal distances for propagules of Sargassum spinuligerum (Sargassaceae, Phaeophyta) measured directly by vital staining and venturi suction sampling. Mar Ecol Prog Ser 79:133-1.38

Kilar JA, Norris JN (1988) Composition, export, and import of drift vegetation on a tropical, plant-dominated, fringingreef platform (Carribbean Panama). Coral Reefs 7:93-103

Kirkman $H$ (1981) The first year in the life history and the survival of the juvenile marine macrophyte, Ecklonia radiata (Turn.) J. Agardh. J Exp Mar Biol Ecol 55:243-254

Kojis BL (1986) Sexual reproduction in Acropora (Isopora) (Coelenterata: Scleractinia): I: A. cuneata and A. palifera on Heron Island reef, Great Barrier. Mar Biol 91:291-309

Lenhardt X (1991) Hydrodynamique des lagons d'atoll et d'île haute en Polynésie française. Coll Etudes \& Thèses, ORSTOM, Paris

Menge BA, Farrell TM, Olson AM, van Tamelen $P$, Turner $T$ (1993) Algal recruitment and the maintenance of a plant mosaic in the low intertidal region on the Oregon coast. J Exp Mar Biol Ecol 170:91-116

Montaggioni L, Richard G, Bourrouilh-Le Jan, Gabrié C, Humbert L, Monteforte $M$, Naim O, Payri C. Salvat B (1985) Geology and marine biology of Makatea, an uplifted atoll, Tuamotu archipelago, French Polynesia. J Coastal Res 1/2:165-171

Morrissey J (1985) Carbon flow through fleshy macroalgae on coral reefs. University of Hawaii, PhD thesis

Norton TA (1992) Dispersal by macroalgae. Br Phycol J 27: 293-301

Norton TA, Fetter R (1981) The settlement of Sargassum muticum propagules in stationary and flowing water. Mar Biol Assoc UK 61:929-940

Okubo A, Levin SA (1989) A theoretical framework for data analysis of wind dispersal of seeds and pollen. Ecology 70 : 329-338

Orth RJ, Luckenbach M, Moore KA (1994) Seed dispersal in a marine macrophyte: implications for colonization and restoration. Ecology 75:1927-1939

Payri CE, Naïm O (1.982) Variations entre 1971 et 1980 de la biomasse et de la composition des populations de macroalgues sur le récif corallien de Tiahura (île de Moorea, Polynésie française). Cryptogam Algol 3:229-240

Payri CE, N'Yeurt ADR (1997) A revised checklist of Polynesian benthic Marine algae. Aust Syst Bot 10:867-910

Editorial responsibility: Otto Kinne (Editor),

Oldendorf/Luhe, Germany
Reed DC, Foster MS (1984) The effects of canopy shading on algal recruitment and growth in a giant kelp forest. Ecology 65:937-948

Reed DC, Laur DR, Ebeling AW (1988) Variation in algal dispersal and recruitment: the importance of episodic events. Ecol Monogr 58:321-335

Reed DC, Amsler CD, Ebeling AW (1992) Dispersal in kelps: factors affecting spore swimming and competency. Ecology 73:1577-1585

Ribbens E, Silander JA Jr, Pacala SW (1994) Seedling recruitment in forests: calibrating models to predict patterns of three seedling dispersion. Ecology 75:1794-1806

Richards SA, Possingham HP, Noye BJ (1995) Larval dispersion along a straight coast with tidal currents: complex distribution patterns from a simple model. Mar Ecol Prog Ser 122:59-71

Santelices B (1990) Patterns of reproduction, dispersal and recruitment in seaweeds. Oceanogr Mar Biol Annu Rev $28: 177-276$

Simpson CJ (1985) Mass spawning of scleractinian corals in the Dampier Archipelago and the implications for management of coral reefs in Western Australia. West Aust Dep Conserv Environ Bull 244

Stiger V (1997) Contribution à l'étude de la biologie des populations de deux grandes algues brunes Turbinaria ornata (Turn.) J. Agardh et Sargassum mangarevense (Grunow) Setchell, proliférant sur les récifs de Polynésie française Thèse de Doctorat, Université Française du Pacifique, Tahiti

Stiger V, Payri C (1999) Spatial and seasonal variations in the biological characteristics of two invasive brown algae Turbinaria ornata (Turner) J. Agardh and Sargassum mangarevense (Grunow) Setchell (Sargassaceae, Fucales) spreading on the reefs of Tahiti (French Polynesia). Bot Mar 42(3):295-306

Stoddart JA, Black R (1985) Cycles of gametogenesis and planulation in the coral Pocillopora damicornis. Mar Ecol Prog Ser 23:153-164

Vadas RL Sr, Johnson S, Norton TA (1992) Recruitrnent and mortality of early post-settlement stages of benthic algae. Br Phycol J 27:331-351

Van den Hoek C (1987) The possible significance of longrange dispersal for the biogeography of seaweeds. Helgol Wiss Meeresunters 41:261-272

Wallace CC (1985) Seasonal peaks and annual fluctuations in recruitment of juveniles scleractinian corals. Mar Ecol Prog Ser. 21:289-298

Submitted: October 27, 1999; Accepted: June 10, 1999

Proofs received from author(s): November 30, 1999 